\title{
In-Vitro Nitric Oxide Scavenging and Anti-Tyrosinase Activity of Two Convolvulus L. Species
}

\author{
İki Convolvulus L. Türünün In-Vitro Nitrik Oksit Süpürme ve Anti-Tirozinaz Aktivitesi
}

\author{
Cennet ÖZAY*
}

Pamukkale Üniversitesi, Fen-Edebiyat Fakültesi, Biyoloji Bölümü, 20070, Denizli

\author{
• Geliş tarihi / Received: 10.03.2018 • • Düzeltilerek geliş tarihi / Received in revised form: 04.11.2018 • Kabul tarihi / Accepted: 07.12.2018
}

\begin{abstract}
Convolvulus L. is a member of Convolvulaceae family which have been utilized for their biological activities in folk medicine. The aim of this study is to investigate the inhibitory effect on tyrosinase activity of two Convolvulus species as well as their nitric oxide (NO) scavenging activity potentials. Up to now, no reports have been found on their antityrosinase and NO scavenging activity properties in the literature. C. galaticus and C. phrygius aerial parts were extracted with methanol and then NO scavenging activity assay was utilized for the assurance of radical scavenging activity of the extracts. Anti-tyrosinase activity of the extracts was determined using the modified 96-well microplate method. The highest NO scavenging and anti-tyrosinase activity were found in C. galaticus as $55.20 \%$ and $53.16 \%$, respectively.
\end{abstract}

Keywords: Convolvulus L.,nitric oxide scavenging activity, plant extract, tyrosinase inhibition

\section{$\ddot{\boldsymbol{O}} \boldsymbol{z}$}

Convolvulus L., Convolvulaceae familyasının bir üyesi olup, biyolojik aktivitelerinden dolayı halk arasında tıbbi amaçlı kullanılmaktadır. Bu çalışmanın amacı, iki Convolvulus türünün tirozinaz aktivite üzerindeki inhibitör etkisi ve nitrik oksit (NO) süpürme aktivite potansiyellerini belirlemektir. Şimdiye kadar yapılan yayınlarda bu iki bitkinin antitirozinaz ve NO süpürme aktivite özelliklerine ilişkin bir rapor bulunamamıştır. C. galaticus ve C. phrygius toprak üstü kısımlart metanolde ekstrakte edildikten sonra ekstraktların radikal süpürme aktivitelerinin belirlenmesi için NO süpürme aktivite deneyi kullanıldl. Ekstraktların anti-tirozinaz aktivitesi, 96-kuyucuklu mikroplaka metodunun modifiye edilmesiyle belirlendi. En yüksek NO süpürme ve anti-tirozinaz aktivitesi C. galaticus'ta sirasiyla \% 55.20 ve \% 53.16 olarak bulundu.

Anahtar kelimeler: Convolvulus L.,nitrik oksit süpürme aktivitesi, bitki ekstraktı, tirozinaz inhibisyonu

\footnotetext{
* Cennet ÖZAY; cennetozay@hotmail.com; Tel: (0 536) 282 76 67; orcid.org/0000-0002-1120-6122
} 


\section{Introduction}

Nitric oxide (NO), which is produced by macrophages, endothelial cells and neurons, is a free radical showing significant reactivity with other free radicals and certain types of proteins (Amaeze et al., 2011). NO has an important role for the regulation of different physiological events, such as vasodilatation (Nagmoti et al., 2011). Low level of NO is adequate in most cases to impact the physiological functions (Bhaskar and Balakrishnan, 2009). Prolonged exposure to NO radical is related to the emergence of lots of serious illness including cancer, arthritis and multiple sclerosis. NO radical can be scavenged by phenolics and removal of free radicals can be possible with the antioxidant activity of phenolics (Lakhanpal and Rai, 2007). In vitro scavenging of NO radical is one of the assays that may be used to figure out the antioxidant activity (Nagmoti et al., 2011).

Tyrosinase (monophenol monooxygenase, EC 1.14.18.1) is a copper-containing enzyme, which is taken part in the first two steps of melanin biosynthesis (Karioti et al., 2007). Melanin formation results in enzymatic browning in human skin and plants. Also, it is known that tyrosinase causes to unwanted changes in taste, scent and nutritious rates of plant-originated foods (Friedman, 1996). Thus, tyrosinase inhibitors have become progressively significant in food, cosmetic and pharmaceutical products in terms of hyperpigmentation (Lim et al., 2009). Some tyrosinase inhibitors have been identified in natural sources from particular plants (No et al., 1999).

Convolvulus is a genus of the Convolvulaceae family comprising about 250 species worldwide (Cronquist, 1981). In Turkey, this genus is represented with about 37 taxa (Aykurt and Sümbül, 2010). Certain Convolvulus species are known for their medicinal utilization and exhibit some biological properties such as antidepressant, antioxidant, antinociceptive, anticancer and neuroprotective activities (Dhingra and Valecha, 2007; Nacef et al., 2010; Atta and El-Sooud, 2004; Sadeghi-Aliabadiet al., 2008; Bihaqi et al., 2009). Previously, the NO scavenging activity of some Convolvulaceae members were reported (Gomathi et al., 2015; Baruah et al., 2014) but there hasn't been found any research on NO scavenging and anti-tyrosinase activity properties of the Convolvulus species in the literature.
The goal of this study was to investigate the NO scavenging activity of two Convolvulus methanolic extracts and to determine their inhibitory effect on tyrosinase activity.

\section{Material and Method}

\subsection{Collection of Plant Material and Extraction}

C. galaticus Rotsan ex Choisy and C. phrygius Bornm. were collected from Eskişehir-Turkey $(900 \mathrm{~m})$ and Antalya-Turkey $(1100 \mathrm{~m})$, respectively. The aerial parts of plants were airdried over shadow at $25^{\circ} \mathrm{C}$, powdered to as a fine grain. Then methanolic extracts were obtained by following the method of Ozay et al (2015). The extracts were lyophilized and stored at $-20^{\circ} \mathrm{C}$ until use.

\subsection{Nitric Oxide Scavenging Activity}

Nitric oxide (NO) was produced from sodium nitroprusside (SNP) which measured as described by Balakrishnan et al (2009) by using the Griess reaction. The mixture containing SNP $(5 \mathrm{mM})$ in PBS ( $\mathrm{pH}$ 7.3), with the plant extracts were prepared in PBS at different concentrations (125$1000 \mu \mathrm{g} / \mathrm{mL}$ ) and incubated for 3 hours at $25^{\circ} \mathrm{C}$. The absorbance value was determined at $546 \mathrm{~nm}$ wavelenght. The positive control was ascorbic acid. The NO scavenging activity was calculated:

NO scavenging activity $(\%)=[(\mathrm{Ac}-\mathrm{At}) / \mathrm{Ac}] \mathrm{x} 100$

where, Ac is the absorbance value of the control, At is the absorbance value of the Convolvulus extracts.

\subsection{Tyrosinase Inhibitory Activity}

Extract solution was mixed with phosphate buffer (pH 6.8) and tyrosinase solution $(33.3 \mathrm{U} / \mathrm{mL})$ in a 96-well microplate and incubated at $23^{\circ} \mathrm{C}$ for 10 min. Then, L-DOPA was added to start the reaction. Likewise, all reaction reagents were added to the extract solution without tyrosinase (blank). After $15 \mathrm{~min}$ incubation at $23^{\circ} \mathrm{C}$, the blank and extract absorbances were measured at 475nm using ELISA microplate reader (Masuda et al., 2005). The percentage inhibition of the tyrosinase activity was calculated:

$I(\%)=\left(A_{0}-A_{1}\right) / A_{0} \times 100$

where, $A_{0}$ is the absorbance value of the control, $A_{1}$ is the absorbance value of the Convolvulus extracts. 


\section{Statistical analysis}

All the assays were performed in triplicate and all the results were presented as mean values and standard deviation (SD). Statistical analysis was conducted by using software SPSS17.0. Duncan test was used to determine the significance of experimental results and $p$-value $<0.05$ was considered to be statistically significant.

\section{Results and Discussion}

\subsection{NO Scavenging Activity}

The free radical scavenging activity of the $C$. galaticus and C. phrygius extracts was determined by NO radical scavenging assay, which was examined by using ascorbic acid as standard. NO created from SNP at appropriate $\mathrm{pH}$ in aqueous solution at physiological interacts with oxygen to generate nitrite ions, which were detected by Griess reagent. Scavengers of NO compete with oxygen leading to decreased formation of $\mathrm{NO}$ (Marcocci et al., 1994). The NO scavenging activity of $C$. galaticus extract was $17.98 \%$ at the minimum concentration of $125 \mu \mathrm{g} / \mathrm{mL}$, whereas the maximum activity was $55.20 \%$ at 1000 $\mu \mathrm{g} / \mathrm{mL}$. Figure 1 shows the percentage of inhibition was increased with rising concentration of the extracts. Nevertheless, the activity of ascorbic acid was more pronounced than that of the extracts of two Convolvulus L. species.

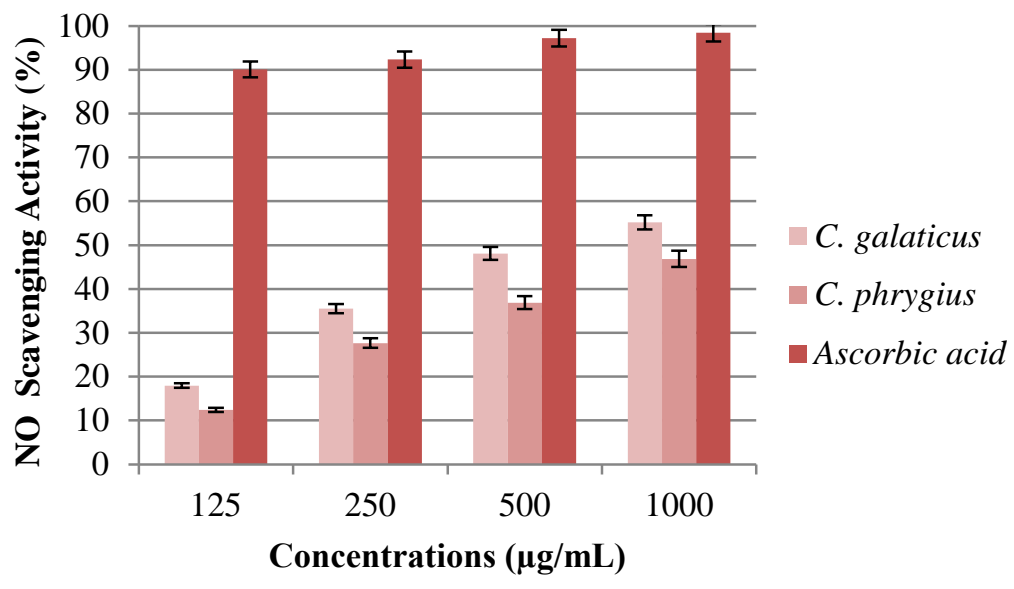

Figure 1. NO scavenging activity of Convolvulus extracts. Data are presented as the mean value \pm SD

It can be concluded that $C$. galaticus extract has higher antioxidant activity than $C$. phrygius. Extracts of several members of Convolvulus, such as $C$. althaeoides (Tawaha et al., 2007), $C$. fatmensis (Atta et al., 2007) have been reported to exhibit antioxidant activity.

\subsection{Anti-tyrosinase Activity}

Tyrosinase inhibitory activity was determined by dopachrome method with L-DOPA as substrate. The inhibitory effect of $C$. galaticus and $C$. phrygius extracts and ascorbic acid (positive control) on biological activity of tyrosinase were shown in Table 1 . It can be clearly seen that tyrosinase inhibitory activity of two Convolvulus L. species increased by rising extract concentration, but this increase was not statistically significant $(\mathrm{P}<0.05)$.
C. galaticus extract has higher anti-tyrosinase activity than $C$. phrygius. The highest tyrosinase inhibitory activity was observed in C. galaticus as $53.16 \%$, while the lowest activity was observed in C. phrygius as $26.18 \%$ at the maximum concentration of $4 \mathrm{mg} / \mathrm{mL}$.

Plants active secondary metabolites are not definitely required for the normal plant growth but responsible for a lot of bioactive compounds used in health of organisms. The most important of secondary metabolites can be classified as alkaloids, phenols, terpenoids, saponins and glicosides (Taiz and Zeiger, 1998). Alkaloids are a class of secondary metabolites which have been accepted as the most characteristic and important chemical compounds in Convolvulus species. Some Convolvulus species contain tropane and pyrrolidine alkaloids (Todd et al., 1995; ElShazlya and Wink, 2008). 
Table 1: Tyrosinase inhibitory activity of methanol extracts from two Convolvulus L. species

\begin{tabular}{|c|c|c|c|}
\hline \multirow{2}{*}{$\begin{array}{c}\text { Concentration } \\
(\mathbf{m g} / \mathbf{m L})\end{array}$} & \multicolumn{3}{|c|}{ Tyrosinase inhibition\% } \\
\cline { 2 - 4 } & C. galaticus & C. phrygius & Ascorbic acid \\
\hline 1 & $26.73^{\mathrm{a}} \pm 0.22$ & $23.46^{\mathrm{a}} \pm 0.42$ & $98.00^{\mathrm{a}} \pm 0.34$ \\
\hline 2 & $28.12^{\mathrm{a}} \pm 0.27$ & $24.15^{\mathrm{a}} \pm 0.34$ & $98.53^{\mathrm{a}} \pm 0.53$ \\
\hline 3 & $52.45^{\mathrm{b}} \pm 0.35$ & $26.00^{\mathrm{a}} \pm 0.41$ & $99.90^{\mathrm{a}} \pm 0.25$ \\
\hline 4 & $53.16^{\mathrm{b}} \pm 0.41$ & $26.18^{\mathrm{a}} \pm 0.45$ & $100.68^{\mathrm{a}} \pm 0.40$ \\
\hline
\end{tabular}

Data are expressed as mean \pm SD.

Different letters within the given column are significantly different at $\mathrm{P}<0.05$.

\section{Conclusion}

From the above results it can be concluded that $C$. galaticus possesses more NO scavenging and antityrosinase activity than $C$. phrygius. These activities may be due to alkaloids probably found in the extracts but further studies should be carried out on the identification of responsible active components.

\section{References}

Amaeze, O.U., Ayoola, G.A., Sofidiya, M.O., Adepoju- Bello, A.A., Adegoke, A.O., Coker, H.A.B., 2011, Evaluation of antioxidant activity of Tetracarpidium conophorum (Mull. Arg) Hutch \& Dalziel leaves, Oxidative Medicine and Cellular Longevity, Article ID 976701, 7 pages.

Atta, A.H., El-Sooud, K.A., 2004, Antinociceptive effect of some Egyptian medicinal plant extracts, Journal of Ethnopharmacology,95, 235-238.

Atta, A.H., Mohamed, N.H., Nasr, S.M., Mouneir, S.M., 2007, Phytochemical and pharmacological studies on Convolvulus fatmensis Ktze., Journal of Natural Remedies, 7, 109-119.

Aykurt, C., Sümbül, H., 2010, Varieties and chorology of C. oleifolius Desr. (Convolvulaceae) in Turkey. Biological Diversity and Conservation, 3(2), 155-162.

Balakrishnan, N., Panda, A.B., Raj, N.R., Shrivastava, A., Prathani, R.B., 2009, The evaluation of nitric oxide scavenging activity of Acalypha indicaLinn Root, Asian Journal Research Chemistry, 2(2), 148-150.

Baruah, N.C., Das, S., Yadav, S.K., 2014, Preliminary Phyto-chemical Analysis and Antioxidant Activities of Methanol Extract of Argyreia roxburghii Choisy, International Journal of Herbal Medicine, 2(1), 126-131.
Bhaskar, H.V. and Balakrishnan, N., 2009, In vitro antioxidant property of laticiferous plant species from Western Ghats Tamilnadu, India, International Journal of Health Research, 2(2), 163-170.

Bihaqi, S.W., Sharma, M., Singh, A.P., Tiwari, M., 2009, Neuroprotective role of Convolvulus pluricaulis on aluminium induced neurotoxicity in rat brain, Journal of Ethnopharmacology, 124,409-415.

Cronquist, A., 1981, An Integrated System of Classification of Flowering Plants. Columbia University Press, NewYork.

Dhingra, D. and Valecha, R., 2007, Evaluation of the antidepressant-like activity of Convolvulus pluricaulis choisy in the mouse forced swim and tail suspention tests. Medical Science Monitor, 13, 155-161.

El-Shazlya, A. and Wink, M., 2008, Tropane and pyrrolidine alkaloids from Convolvulus lanatus Vahl, Zeitschrift für Naturforschung, 63c, 321325 .

Friedman, M., 1996, Food browning and its prevention: An overview. Journal of Agricultural and Food Chemistry, 44, 631-653.

Gomathi, D., Ravikumar, G., Kalaiselvi, M., Vidya, B., Uma, C., 2015, In vitro free radical scavenging activity of ethanolic extract of the whole plant of Evolvulus alsinoides (L.) L. Chinese Journal of Integrative Medicine, 21(6), 453-458.

Karioti, A., Protopappa, A., Megoulas, N., Skaltsa, H., 2007, Identification of tyrosinase inhibitors from Marrubium velutinum and Marrubium cylleneum, Bioorganic \& Medicinal Chemistry, $15,2708-2714$.

Lakhanpal, P. and Rai, D.K., 2007, Quercetin: a versatile flavonoid, Internet Journal of Medical Update, 2(2), 22-37.

Lim, T.Y., Lim, Y.Y., Yule, C.M., 2009, Evaluation of antioxidant, antibacterial and antityrosinase 
activities of four Macaranga species, Food Chemistry, 114, 594-599.

Marcocci, L., Maguire, J.J., Droy-Lefaix, M.T., Packer, L., 1994, The nitric oxide scavenging properties of Ginkgo bilobaextract EGb 76J, Biochemical and Biophysical Research Communications, 201, 748-755.

Masuda, T., Yamashita, D., Takeda, Y., Yonemori, S., 2005, Screening for tyrosinase inhibitors among extracts of seashore plants and identification of potent inhibitors from Garciniasubelliptica, Bioscience Biotechnology and Biochemistry, 69(1), 197-201.

Nacef, S., Jannet, H.B., Abreu, P. and Mighri, Z., 2010, Phenolic constituents of Convolvulus dorycnium L. flowers, Phytochemistry Letters, 3, 66-69.

Nagmoti, D.M., Khatri, D.K., Juvekar, P.R., Juvekar, A.R., 2011, Antioxidant activity and free radical-scavenging potential of Pithecellobium dulce Benth seed extracts, Free Radical andAntioxidants, 2(2), 37-43.

No, J.K., Soung, D.Y., Kim, Y.J., Shim, K.H., Jun, Y.S., Rhee, S.H., 1999, Inhibition of tyrosinase by green tea components, Life Science, 65, 241246.

Ozay, C., Mammadov, R., Tasdelen, G., Karagur, E.R., Akca, H., 2015, Potential antioxidant, antiproliferative and hepatoprotective effects of Crataegus meyeri, Journal of Food Biochemistry,39,548-553.

Sadeghi-Aliabadi, H., Ghasemi, N., Kohi, M., 2008, Cytotoxic effect of Convolvulus arvensis extracts on human cancerous cell line. Research in Pharmaceutical Sciences,3(1), 31-34.

Taiz, L. and Zeiger, E., 1998, Plant Physiology, 2nd Edition, Sinauer Associates Publishers, pp. 778, Massachusetts.

Tawaha, K., Alali, F.Q., Gharaibeh, M., Mohammad, M., El-Elimat, T., 2007, Antioxidant activity and total phenolic content of selected Jordanian plant species, Food Chemistry, 104, 1372-1378.

Todd, F.G., Stermitz, F.R., Schultheis, P., Knight, A.P., Traub-Dargatz, J., 1995, Tropane alkaloids and toxicity of Convolvulus arvensis, Phytochemistry,39, 301-303. 